\title{
The Impact of CEOs' Compensations on Cost Stickiness in Industrial Companies Listed on the Amman Stock Exchange
}

\author{
Lina Fuad Hussien ${ }^{1}$ \\ ${ }^{1}$ Department of Accounting, Jerash University, Jerash, Jordan \\ Correspondence: Lina Fuad Hussien, Department of Accounting, Jerash University, Jerash, Jordan.
}

Received: January 17, 2021

Accepted: January 26, 2021

Online Published: January 27, 2021

doi:10.5539/mas.v15n1p152

URL: https://doi.org/10.5539/mas.v15n1p152

\begin{abstract}
The purpose of this study is to analyze the asymmetry in cost behavior (cost stickiness) and to identify the impact of CEOs' compensation on the degree of cost stickiness behavior. The study population consists of the public shareholding companies listed on the ASE, which number (56) industrial company. Data were collected from (35) industrial companies for the period (2009 - 2019). To measure the degree of costs stickiness, The Model of Weiss (2010) was used. The Model of Weiss (2010) takes into account the costs and changes in the level of activity (sales) for the last four quarters of the company, Weiss (2010) model constructs the difference in logarithmic ratios of changes in cost. The study found that the CEO's compensation in Jordanian industrial companies consists of two forms. The companies pay fixed salaries or performance-related bonuses. The study found that the form of compensation that is paid to the CEO affects the behavior of managers. The results indicated that the performance-related rewards are accompanied by a decrease in the level of cost stickiness, and the compensation paid in the form of fixed salaries are accompanied by a high level of cost stickiness. The study recommends that companies should understand the role of the compensation form in administrative decisions, especially with regard to resource modifications, as management motives in relation to resource modifications must be taken into account because of their clear and direct impact on the cost structure of companies.
\end{abstract}

Keywords: CEOs' compensations, cost stickiness, agency problem, asymmetric cost behavior

\section{Introduction}

\subsection{Study Background}

The study of cost behavior is of great importance in companies regardless of their size, the type of sector to which they belong, or the type of activity they practice, especially in light of the prevailing market economies, and the resulting competition between them, not only because the costs are related to production savings, However, because they are highly relevant to the process of supervision and control and the formulation of price, marketing, and production policies, costs play a key role in determining the price and quantities produced, and can affect the degree of monopoly in the markets (Sugiri et al., 2017). If the estimated cost functions are inadequate or do not reflect the true reality of the cost behavior, all decisions based on these costs become inappropriate and may lead to short- and long-term losses. Therefore, researchers, managers, investors, and others were interested in studying cost functions to make administrative, investment, financing, and other decisions (Lee et al., 2019).

Many studies have found that costs do not change in proportion to the change in revenue, as they have shown that costs increase in response to increased revenues but do not decrease when revenues fall by the same percentage, ie, its response to decrease in revenues differently than the level of response in the case of higher revenues. This denies the prevailing belief in economic and accounting thought (Anderson et al., 2003). Costs that are asymmetric in their behavior are called (Sticky Costs). The concept of consistent behavior of variable costs contradicts the modern concept of cost behavior, which proved that variable cost behavior does not change in proportion to the volume of activity (Yasukata \& Kajiwara 2011).

Many studies document that performance-based compensation tends to motivate managers to work for the benefit of shareholders (Jensen \& Meckling, 1976; Gigliotti, 2013; Anderson et al., 2010). But agency theory suggests that managers will act opportunistically when their interests differ from the interests of the owners in the absence of effective monitoring and control mechanisms (Eisenhardt, 1989). According to stakeholder theory, 
various aspects of total compensation can occur in line with several organizational performance objectives, balance between internal and external objectives, and the selection and retention of skilled executives (Werner et al., 2005), so total compensation is linked to a variety of practices that are consistent With stakeholders' wishes, the compensation package consists of a desirable package that can meet the expectations and preferences of the CEO (Al-Najjara et al., 2016).

According to Bosch et al., (2017) in case of low sales, managers may either decide to cut costs in order to maintain the current level of profitability or they may decide to retain resources for possible future growth. According to agency theory, managers make investment decisions with the aim of maximizing their own benefits (rather than those of corporate shareholders) in order to build a managers' empire through misallocation of resources in companies, especially when working in an unstable and uncertain environment (Jensen \& Meckling, 1976; Chen et al., 2012).

\subsection{Study Problem}

Numerous studies in the field of CEO compensation incentives have indicated that in order to improve the future performance of companies, companies should improve the quality of incentive mechanisms for CEO, such as relying on stock options, restricted shares and profit-sharing schemes for CEO. An effective compensation system can push CEOs to make management decisions that maximize shareholder wealth and help improve the company (Chen et al., 2012). On the contrary, an ineffective compensation system may dampen CEO' enthusiasm and reduce their interest in the future performance of companies (Jensen \& Murphy, 1990). Several studies also have attempted to detect factors that influence asymmetric cost behavior (cost stickiness) and it's found that there are many factors such as CEO compensations, adaptation costs, managers' optimism, asset intensity, debt intensity, and other factors that have a strong impact on cost stickiness level (Dierynck, landsman, \& Renders 2012; Kama \& Weiss, 2013; Bruggen \& Zehnder, 2014).

In In this study, emphasis is placed on future sales forecasts and capacity utilization, which accounting studies indicate that are possible explanations for the relationship between cost behavior and company performance (Bruggen \& Zehnder, 2014). The literature indicates that one of the reasons for the management not being quick to respond to low performance is the expectation of improved performance in the short term (Anderson et al., 2007). The literature also indicates that cost behavior is related to the interaction between changes in activity (sales) and the level of capacity utilization (Balakrishnan et al., 2004). When the activity level decreases, the unused energy appears because a portion of the energy is constant due to the stickiness of costs (Anderson et al., 2007). Whereas, when sales decrease, the expense to sales ratio will increase, leading to a decrease in financial performance indicators (Anderson et al., 2007). In addition, when there is uncertainty about future demand, firms must bear costs to reduce untapped capacity, and here CEOs may take decisions to delay cuts in unused capacity until they become more certain about the continuing decline in demand (Anderson et al., 2007). Which may affect compensation that may determine management behavior in how to respond to the company's excess capacity. Based on this discussion, we intend to link cost stickiness with administrative compensation to find out whether the compensation system affects the managers 'behavior in adjusting resources, and are the managers' decisions motivated by personal interest or are they decisions aimed at maximizing shareholder benefit. The study problem can be expressed by the following question:

Is there an impact on the CEOs' compensation (salaries, reward) on the degree of cost stickiness in the public shareholding industrial companies listed on the ASE?

\section{Theoretical Foundation \& Hypotheses Development}

The phenomenon of cost stickiness may happen from the intentional administrative decisions, which could be classified as rational or irrational decisions, and here the managerial choice can be viewed as rational when management works for the benefit of a company, meaning that it is rational from the perspective of the company, and is not rational otherwise (Lopatta et al., 2020). According to the agency's interpretation, cost stickiness appears through the processes of fully capable and qualified managers, but motivated by their self-interested (Bruggen \& Zehnder, 2014), whereby the self-interested managers maximize their private benefit even if their actions splay from the interests of the shareholders (Jensen \& Meckling, 1976). It is therefore irrational from a firm's perspective, and the accounting literature has identified two drivers of agency for asymmetric cost behavior: "Empire building incentives" and "earnings management incentives". Empire building describes the agency problem in administrative activities aimed at benefiting from the size of the firm (Jensen, 1986). Because of fear of losing respects, power, or compensation, managers view the company's development beyond its optimum size or keep excess resources. Resulting in an ineffective high level of cost stickiness. Chen, Lu, and 
Sougiannis (2012) empirically took up this question and documented that cost asymmetry increases with incentives to build a manager's empire and weakens this link with stronger corporate governance.

Nevertheless, CEOs incentives may lead to an ineffective low level of cost stickiness, since based on past findings showing that agency considerations compel managers to reduce costs to achieve profit targets. Kama and Weiss (2013) argue that self-interested managers maximize their utility private rather than firm value this will reduce redundant resources, even if lower demand is assessed as temporary and downward adjustment is not optimal from a firm's value maximization perspective. Empirical evidence confirming the hypothesis of a negative association between CEOs incentives to achieve profit targets and the level of cost stickiness is provided by Dierynck, Landsman, and Renders (2012) in Belgian private companies, and by Kama and Weiss (2013) using US company data. According to Anderson et al. (2003) model, the directors 'decisions to keep unused costs may also be the result of the personal considerations of the managers, as the managers act as agents for the shareholders, here, the interests of the managers and the interests of the shareholders differ. On the one hand, shareholders want to reduce costs, improve sales revenues, and improve operating efficiency in order to maximize the value of companies. Here, managers tend to pursue their own goals that may not always coincide with the goals of shareholders, and therefore the conflict of interest between managers and shareholders gives managers incentives to pursue their personal benefits.

As discussed above, managers can make a management intervention to reduce or maintain unused costs, as managers can choose to reduce costs by looking at corporate development; Conversely, managers may choose to keep unused costs to their personal interests. In this context, the Anderson et al. (2003) model predicts that self-interested incentives for managers may shift the cost to a higher degree of stickiness. Dierynck, Landsman and Renders (2012) found that the degree of cost stickiness is lower when managers need to achieve or exceed the profit target, and this result indicates that managers have to reduce unused costs when they face profit pressure. Kama and Weiss (2013) also found that when managers want to meet analysts' expectations or to avoid falling profits, they reduce unused costs as sales revenue decrease. These results indicate that managers 'self-interest incentives shift the stickiness of costs to a higher degree; The degree of stickiness can be reduced when the behavior of managers is restricted.

Thus, managers with self-interest incentives will not choose to maximize corporate value but will commit value destructive behavior. In this context, researchers argue that managers' self-interest incentives are a key aspect of analyzing the corporate cost structure. In line with previous research, findings by Chen, Lu and Sougiannis (2012) demonstrate that the empire-building incentives that are interpreted as agency problems are positively related to the level of stickiness in administrative, sales and general costs. Based on concerns about agency problems, Anderson et al. (2003) model suggests that sticky costs may exist due to the fact that managers intentionally adjust costs in response to changes in sales revenue, as managers have incentives to avoid the pressures of reducing sales revenue or possible complaints from dismissed employees. Anderson et al. (2003) argue that managers have incentives to keep unused costs at certain levels in order to retain personal benefits, and from the perspective of agency struggles, Chen, Lu and Sougiannis (2012) showed through empirical research that incentives for empire building correlate positively with the stickiness of administrative support costs, thus supporting that self-interest incentives of managers increase the degree of cost stickiness. Bebchuk et al. (2011) indicates that administrative compensation represents the ability of management to extract its benefits. According to agency theory, management compensation is likely to increase cost stickiness due to higher agency costs. On the contrary, stewardship theory indicates that management compensation is more likely to reduce cost stickiness because management is not an opportunistic agent. Bugeja, Lu and Shan (2015) also documented the argument for resource adjustment costs and administrative incentives. Their study finds that cost stickiness in Australia increases when managers have strong incentives to avoid a decline in profits or losses.

Management compensation can coincide with an increase in liabilities (De Angelis \& Grinstein, 2015) and is thus expected to result in a higher default risk, which leads to increased risk aversion for managers. Assuming that the degree of cost stickiness arises mainly from the good intention of managers to enhance the value of the company, the increased risk of default will induce managers to increase the level of cost stickiness, as the increase in cost in this case is expected to improve the value of the company and reduce the risk of default. In this case, the economic factor of cost stickiness predicts the existence of a positive correlation between the administrative compensation and the level of cost stickiness. On the contrary, if the cost stickiness is primarily due to the managers' self-interest, then the managers who are increasingly risk averse will be more conservative about the company's future performance. This will lead to the adoption of more conservative policies with less incentive to hold resources during recessions if the level of activity decreases. This will reduce the stickiness of cost. Here it can be said that the degree of cost stickiness is negatively related to management compensation. 
Based on the above discussion, the following hypotheses can be formulated:

Ho1: Costs in the industrial public shareholding companies do not follow the asymmetry behavior.

Ho2: There is no statistically significant effect at the level of $(\alpha \leq 0.05)$ for CEOs compensation (salaries, administrative reward) on the degree of cost stickiness in industrial public shareholding companies listed on the ASE.

This main hypothesis is divided into the following sub-hypotheses:

Ho2-1: There is no statistically significant effect at the level of $(\alpha \leq 0.05)$ for CEOs salaries on the degree of cost stickiness in industrial public shareholding companies listed on the ASE.

Ho2-2: There is no statistically significant effect at the level of $(\alpha \leq 0.05)$ for CEOs reward on the degree of cost stickiness in industrial public shareholding companies listed on the ASE.

\section{Study Methodology}

\subsection{Study Population and Sample}

The study population consists of the public shareholding companies listed on the ASE, which number according to the Securities Depository Center (SDC) of Jordan (56) industrial company. The purpose of this study is to analyze the asymmetry in cost behavior (cost stickiness) and to identify the impact of CEOs' compensation on the degree of cost stickiness behavior. For this purpose, data were collected from (35) industrial companies for the period (2009 - 2019). The study sample includes companies that have data available for the mentioned period; otherwise, the company is excluded.

The companies that met the following criteria combined were selected:

1. The company data must be available during the study period.

2. The company has not been subjected to liquidation or merger cases.

3. The operations of the company did not stop during this period.

4. The company has not been subject to financial failure or bankruptcy.

5. The company's shares did not cease trading during the study period.

\subsection{Sources of Data Collection}

The study relied on secondary data, by reference to books and studies related to the subject of this study, and for the purposes of analysis, the websites of the companies included in the study sample were used to obtain the financial statements.

\subsection{Measurement of Study Variables}

\subsubsection{Cost Stickiness}

To measure the degree of costs stickiness, The Model of Weiss (2010) was used. The Model of Weiss (2010) takes into account the costs and changes in the level of activity (sales) for the last four quarters of the company, as the calculations are based on company data from most recent as sales decreased and the fourth quarter as sales increased. For the quadrants chosen, Weiss (2010) model constructs the difference in logarithmic ratios of changes in cost. The following equation represents the model used:

$$
\operatorname{STICK} Y_{i, t}=-\left[\log \left(\frac{\Delta \operatorname{COST} T}{\Delta S A L E}\right)_{i, \underline{\tau}}-\log \left(\frac{\Delta \operatorname{COST}}{\Delta S A L E}\right)_{i, \bar{\tau}}\right] \text { With } \underline{\tau}, \bar{\tau} \in\{t, \ldots, t-3\}
$$

Where:

STICKY $Y_{i, t}$ : The level of costs stickiness on a quarterly basis for the company $(i)$ in the quarter $(t)$.

$\underline{\tau}:$ Is the recent quarter of the last four quarters with a decrease in sales.

$\bar{\tau}:$ Is the recent quarter of the last four quarters with an increase in sales.

$\triangle S A L E: S A L E_{i, t}-S A L E_{i, t-1}$.

$\triangle C O S T:\left(\operatorname{SALE}_{i, t}-\right.$ EARINGS $\left._{i, t}\right)-\left(\operatorname{SALE}_{i, t-1}-\right.$ EARINGS $\left._{i, t-1}\right)$.

EARINGS: Net income before extraordinary items (operating income).

Therefore, the lower value of STICKY means a higher level of costs stickiness. The logarithmic scale is driven by cross-firm comparability and mitigation of potential "heteroscedasticity". 


\subsubsection{Compensations of Directors}

CEO's salaries (SALARY): Total gross annual amounts due to members of the Board of Directors disclosed in the financial reports and clarifications of the sample study companies.

DEO's reward (REWARD): Total amounts due to directors as annual bonuses, travel expenses or other annual benefits, as disclosed in the financial reports and notes of the sample companies.

\subsubsection{Control Variables}

Return on asset $(R O A)$ : Ratio of operating income to total assets.

Leverage ( $L E V)$ : The level of leverage.

Size (SIZE): Logarithm of lagged total assets.

Capital intensity $(C A P R)$ : measured as the net value of fixed assets scaled by operating revenue.

3.4 Model Specification

$$
\begin{aligned}
& \text { STICKY }_{\text {it }}=a_{0}+a_{1} * \operatorname{REWARD}_{\text {it }}+\mathrm{a}_{2} \operatorname{ROA}_{\text {it }}+\mathrm{a}_{3} * \operatorname{LEV}_{\text {it }}+\mathrm{a}_{4} * \operatorname{SIZE}_{\text {it }}+\mathrm{a}_{5} * \operatorname{CAPR}_{\text {it }}+\mathrm{e}_{\mathrm{i}} \\
& \text { STICKY }_{\text {it }}=\mathrm{b}_{0}+\mathrm{b}_{1} * \operatorname{SALARY}_{\text {it }}+\mathrm{b}_{2} \operatorname{ROA}_{\text {it }}+\mathrm{b}_{3} * \operatorname{LEV}_{\text {it }}+\mathrm{b}_{4} * \operatorname{SIZE}_{\text {it }}+\mathrm{b}_{5} * \operatorname{CAPR}_{\text {it }}+\mathrm{e}_{\mathrm{i}}
\end{aligned}
$$

\subsection{Methods of Data Analysis}

In this study, the descriptive method of collection and analysis of data and the method of cross-sectional data over time (PANEL DATA) was used to find the relationship of cause and effect between the various variables at different time periods (Zraqat, 2019). This period extends from 2009 to 2019. Therefore, descriptive analysis (mean, median, minimum, the standard deviation, the use of the fixed-effect model (FEM).

\section{Results}

\subsection{Descriptive Statistics of the Study Variables}

Table 1. Descriptive Statistics

\begin{tabular}{lllll}
\hline & Mean & Stdev. & Min & Max \\
\hline SALARY & 85,317 & 90,761 & 0 & 415,168 \\
REWARD & 61,969 & 103,987 & 0 & 616,603 \\
STICKY & 0.086 & 0.491 & -1.835 & 1.471 \\
ROA & 1.740 & 9.307 & -23.039 & 40.384 \\
LEV & 35.489 & 19.474 & 6.385 & 86.536 \\
SIZE & 17.156 & 1.305 & 14.623 & 20.915 \\
CAPR & 1.984 & 12.264 & 0.049 & 172.451 \\
\hline
\end{tabular}

\subsection{Empirical Results}

This study employs the econometric analysis using panel data, before estimating study model, multicollinearity should be tested, in addition to Breusch-pagan LM and Hausman tests, the results shown in table 2.

Table 2. Breusch-pagan LM and Hausman tests

\begin{tabular}{lllll}
\hline Variables & VIF & Hypothesis & Berush-Pagan LM Test & Hausman Test \\
\hline SALARY & 1.093 & \multirow{H}{*}{$\mathrm{H} 01$} & $\mathrm{Chi}^{2}=112.704$ & $\mathrm{Chi}^{2}=0.0745$ \\
REWARD & 1.115 & & $\mathrm{p}$-value $=0.000$ & $\mathrm{p}$-value $=0.999$ \\
$R O A$ & 1.268 & & & \\
LEV & 1.290 & & & \\
SIZE & 1.072 & & $\mathrm{Chi}^{2}=123.857$ & $\mathrm{Chi}^{2}=0.0698$ \\
CAPR & 1.026 & $\mathrm{H} 02$ & $\mathrm{p}$-value $=0.000$ & $\mathrm{p}$-value $=0.999$
\end{tabular}

The results of variance inflation factor (VIF) were less than 5 . This shows that there is no multicollinearity problem among independent variables. Moreover, Berush-Pagan LM \& Hausman tests show random effect model is the best for estimating study models. 
Table 3. Hypotheses testing results (dependent variable: sticky cost)

\begin{tabular}{lll}
\hline & H01 & H02 \\
\hline SALARY & $-0.204^{* *}$ & --- \\
$R E W A R D$ & -- & $0.023^{* *}$ \\
$R O A$ & $0.011^{* *}$ & $0.007^{* *}$ \\
$L E V$ & -0.004 & $-0.003^{* *}$ \\
$S I Z E$ & 0.034 & -0.009 \\
$C A P R$ & 0.002 & 0.001 \\
R-squared & $\mathbf{0 . 1 2 7}$ & $\mathbf{0 . 1 4 3}$ \\
Adj R-squared & $\mathbf{0 . 1 0 6}$ & $\mathbf{0 . 1 2 1}$ \\
F- value & $\mathbf{5 . 8 1 2}$ & $\mathbf{6 . 4 7 4}$ \\
Sig.F & $\mathbf{0 . 0 0 0}$ & $\mathbf{0 . 0 0 0}$
\end{tabular}

Table 3 presents the results of random effect regression on the relationship between salary and sticky cost (H01), and between rewards and sticky cost (H02). As shown in table 3. Salary negatively and significantly influences sticky cost level, whereas, rewards positively and significantly influence sticky cost level. This gives a clear indicator about both type of board compensation, and their effect on sticky cost.

\section{Conclusions and Recommendations}

The CEO's compensation in Jordanian industrial companies consists of two forms. The companies pay fixed salaries (fixed-wage package) or performance-related bonuses, which is a variable amount that is used in order to align the interests of shareholders and the interests of managers. The study found that the form of compensation that is paid to the CEO affects the behavior of managers, which is in line with what Kama and Weiss (2013) indicated, as they indicated that self-interested managers increase their own benefit rather than the value of the company. In this study, the effect of each form of the CEO's compensation on cost behavior was studied. The results indicated that the performance-related rewards (REWARD) are accompanied by a decrease in the level of cost stickiness in the Jordanian industrial companies, meaning that the management takes quick decisions in adjusting resources in order not to affect performance indicators. The compensation paid in the form of fixed salaries $(S A L A R Y)$ is accompanied by a high level of cost stickiness. In the sense that the management is indifferent to performance indicators, this is due to the fact that performance will not affect their salaries because they are fixed regardless of the company's results.

This result is consistent with the empirical evidence confirming the hypothesis of a negative correlation between CEO incentives to achieve profit goals and the level of cost stickiness that was presented by Dierynck et al. (2012) and Kama and Weiss (2013). Where managers 'decisions to keep unused costs may be the result of managers' personal considerations, where the director's act as agents of the shareholders, here the interests of the directors and the interests of the shareholders differ as Managers may choose to keep unused costs in their own interests. In this context, Anderson et al (2003) found that managers 'self-interest incentives may shift the cost to a higher degree of stickiness when they do not have the incentive to influence the firm's results, which is consistent with our findings as the fixed-wage package was associated with higher levels of cost stickiness. Also, the degree of cost stickiness is lower when the managers need to achieve or exceed the profit goal when their reward is related to performance since managers have to reduce unused costs when they are facing pressure on profit, this is in line with Dierynck et al. (2012). Consequently, managers with self-interest incentives will not choose to maximize the value of the company but will commit value destructive behavior.

These results can be interpreted according to agency theory, as management compensation is likely to increase cost stickiness due to higher agency costs. On the contrary, stewardship theory indicates that compensation of management is more likely to reduce cost stickiness because management is not an opportunistic agent. our results are consistent with that of Bugeja et al. (2015) suggest that cost stickiness in Australia increases when managers have strong incentives to avoid declining profits or losses. This result can also be interpreted in light of what predicts the economic factor of cost stickiness, as management compensation can coincide with an increase in liabilities and thus is expected to lead to a higher risk of default, leading to increased risk aversion for managers (De Angelis \& Grinstein, 2015). Whereas, the increased risk of default will induce managers to increase the level of cost stickiness, as the increase in cost is expected to improve the value of the company and reduce the risk of default. On the contrary, if the increase in the level of cost stickiness is primarily due to the 
self-interest of managers, the managers who are increasingly risk-averse will be more conservative with less incentive to hold resources during recessions if the level of activity decreases, this will reduce the stickiness of cost.

The study recommends that companies should understand the role of the compensation form in administrative decisions, especially with regard to resource modifications, as management motives in relation to resource modifications must be taken into account because of their clear and direct impact on the cost structure of companies. Corporate departments must also make resource adjustments to achieve a balance between future sales growth and current performance. And that the combination of fixed salaries and performance-based bonuses will contribute to solving the agency problem, and increase the compatibility between the interests of the owners and the interests of management.

\section{References}

Al-Najjara, B., Dingb, R., \& Hussaineyc, K. (2016). Determinants and value relevance of UK CEO pay slice. International Review of Applied $\quad$ Economics, $30(3), \quad 403-421$. https://doi.org/10.1080/02692171.2015.1105938

Anderson, M. C., Banker, R. D., Huang Rong, \& Janakiraman, S. N. (2007). Cost Behavior and Fundamental Analysis of SG\&A Costs. Journal of Accounting, Auditing \& Finance, 22(1), 1-28. https://doi.org/10.1177/0148558X0702200103

Anderson, M., Banker, R., Huang, R., \& Janakiraman, S. (2003). Are Selling, General, and Administrative Costs "Sticky"? Journal of Accounting Research, 41(1), 47-63. https://doi.org/10.1111/1475-679X.00095

Anderson, S. W., Dekker, H. C., \& Sedatole, K. L. (2010). An empirical examination of goals and performance-to-goal following the introduction of an incentive bonus plan with participative goal setting. Management Science, 56(1), 90-109. https://doi.org/10.1287/mnsc.1090.1088

Balakrishnan, R., Labro, E., \& Soderstrom, N. S. (2014). Cost structure and sticky costs. Journal of Management Accounting Research, 26(2), 91-116. https://doi.org/10.2308/jmar-50831

Bebchuk, L., Cremers, M., \& Peyer, U. (2011). The CEO pay slice. Journal of Financial Economics, 102(1), 199-221. https://doi.org/10.1016/j.jfineco.2011.05.006

Bosch, J., Blandon, J., Ravenda, D., Silva, M., \& Somoza, A. (2017). The Influence of the Trade-Off between Profitability and Future Increases in Sales on Cost Stickiness. Estudios de Economia, 44(1), 81-104. https://doi.org/10.4067/S0718-52862017000100081

Bruggen, A., \& Zehnder, J. (2014). SG\&A cost stickiness and equity-based executive compensation: does empire building matter? Journal of Management Control, 25(3-4), 169-192. https://doi.org/10.1007/s00187-014-0195-5

Brüggen, A., \& Zehnder, J. O. (2015). SG\&A cost stickiness and equity-based executive compensation: does empire building matter? J Manag Control, 25, 169-192. https://doi.org/10.1007/s00187-014-0195-5

Bugeja, M., Lu, M., \& Shan, Y. (2015). Cost Stickiness in Australia: Characteristics and Determinants. Australian Accounting Review (AAR), 25(3), 248-261. https://doi.org/10.1111/auar.12066

Chen, C. X., Lu, H., \& Sougiannis, T. (2012). The agency problem, corporate governance, and the asymmetrical behavior of selling, general, and administrative costs. Contemporary Accounting Research, 29(1), $252-282$. https://doi.org/10.1111/j.1911-3846.2011.01094.x

De Angelis, D., \& Grinstein, Y. (2015). Performance terms in CEO compensation contracts. Review of Finance, 19(2), 619-651. https://doi.org/10.1093/rof/rfu014

Dierynck, B., W. R. Landsman, \& A. Renders. (2012). Do managerial incentives drive cost behavior? Evidence about the role of the zero earnings benchmark for labor cost behavior in Belgian private firms. The Accounting Review, 87(4), 1219-1246. https://doi.org/10.2308/accr-50153

Eisenhardt, K. (1989). Agency theory: an assessment and review. Academy of Management Review, 14(1), 57-74. https://doi.org/10.2307/258191

Gigliotti, M. (2013). The compensation of top managers and the performance of Italian firms. The International Journal of Human Resource Management, 24(4), 889-903. https://doi.org/10.1080/09585192.2012.702317

Jensen, M. C. (1986). Agency costs of free cash flow, corporate finance, and takeovers. The American Economic Review, 76(2), 323-329. Retrieved from https://www.jstor.org/stable/1818789 
Jensen, M. C., \& Meckling, W. H. (1976). Theory of the firm: Managerial behavior, agency costs and ownership structure. Journal of Financial Economics, 3(4), 305-360. https://doi.org/10.1016/0304-405X(76)90026-X

Jensen, M. C., \& Murphy, K. J. (1990). Performance pay and top-management incentives. Journal of Political Economy, 98(2), 225-264. https://doi.org/10.1086/261677

Kama, I., \& Weiss, D. (2010). Do Managers' Deliberate Decisions Induce Sticky Costs? SSRN Electronic Journal. https://doi.org/10.2139/ssrn.1558953

Kama, I., \& Weiss, D. (2013). Do earnings targets and managerial incentives affect sticky costs? Journal of Accounting Research, 51(1), 201-224. https://doi.org/10.1111/j.1475-679X.2012.00471.x

Lee, J., Park, J.-H., \& Hyeon, J. (2019). Co-CEOs and Asymmetric Cost Behavior. Sustainability, $11,1046$. https://doi.org/10.3390/su11041046

Lopatta, K., Kaspereit, T., \& Gastone, L. M. (2020). Managerial style in cost asymmetry and shareholder value. Managerial and Decision Economics, 41(5), 800-826. https://doi.org/10.1002/mde.3139

Sugiri, S., Febrianto, R., \& Kresnawati, E. (2017). Sticky cost behavior of bank's executive compensation in four South East Asian countries. Journal of Economics, Business, and Accountancy Ventura, 19(3), 363-376. https://doi.org/10.14414/jebav.v19i3.771

Weiss, D. (2010). Cost behavior \& analysts' earnings forecasts. The Accounting Review, 85(4), 1441-1471. https://doi.org/10.2308/accr.2010.85.4.1441

Werner, S., Tosi, H. L., \& Gomez-Mejia, L. (2005). Organizational governance and employee pay: How ownership structure affects the firm's compensation strategy. Strategic Management Journal, 26(4), 377-384. https://doi.org/10.1002/smj.452

Yasukata, K., \& Kajiwara, T. (2011). Are "sticky costs" the result of deliberate decision of managers? https://doi.org/10.2139/ssrn.1444746

Zraqat, O. M. (2019). Sustainability Practices Disclosure and Value Relevance: Evidence from Jordan. Modern Applied Science, 13(9), 75-86. https://doi.org/10.5539/mas.v13n9p75

\section{Copyrights}

Copyright for this article is retained by the author(s), with first publication rights granted to the journal.

This is an open-access article distributed under the terms and conditions of the Creative Commons Attribution license (http://creativecommons.org/licenses/by/4.0/). 